H. V. Bilavych ${ }^{1}$ ORCID https://orcid.org/0000-0002-1555-0932

M. A. Bahriy ${ }^{1}$ ORCID https://orcid.org/0000-0002-3506-9900

I. V. Bilavych ${ }^{2}$ ORCID https://orcid.org/0000-0003-4561-4690

B. P. Savchuk ${ }^{1}$ ORCID https://orcid.org/0000-0003-2256-0845

N. O. Fedchyshyn ${ }^{3}$

ORCID https://orcid.org/0000-0002-0909-4424

${ }^{1}$ Vasyl Stefanyk Precarpathian National University

${ }^{2}$ Warsaw Medical University,Warsaw, Poland

${ }^{3}$ I. Horbachevsky Ternopil National Medical University

\title{
THE CONTRIBUTION OF DOCTORS, MEMBERS OF THE SHEVCHENKO SCIENTIFIC SOCIETY IN LVIV TO THE DEVELOPMENT OF UKRAINIAN EDUCATION, SCIENCE AND LITERATURE (LATE XIX - EARLY XX CENTURY)
}

\author{
Г. В. Білавич ${ }^{1}$, М. А. Багрій ${ }^{1}$, І. В. Білавич ${ }^{2}$, Б. П. Савчук ${ }^{1}$, Н. О. Федчишин ${ }^{3}$ \\ ${ }^{1}$ ДВНЗ «Прикарпатський національний університет імені Василя Стефаника» \\ ${ }^{2}$ Варшавський медичний університет, Варшава, Республіка Польща \\ ${ }^{3}$ Тернопільський національний медичний університет \\ імені І. Я. Горбачевського МОЗ Украӥни

\section{ВНЕСОК ЛІКАРІВ, ЧЛЕНІВ НАУКОВОГО ТОВАРИСТВА ІМЕНІ ШЕВЧЕНКА У ЛЬВОВІ, У РОЗВИТОК УКРАЇНСЬКОЇ ОСВІТИ, НАУКИ, ЛІТЕРАТУРИ (КІНЕЦЬ ХІХ - ПОЧАТОК ХХ СТ.)}

\begin{abstract}
The article analyzes the contribution of some Ukrainian doctors (who were also writers) of Halychyna in the development of education and science. Scientific achievements of I. Horbachevskyi, Ya. Okunevskyi, S. Okunevska-Morachevska, Ye. Ozarkevych and others through the prism of activity of the Shevchenko Scientific Society in the early XX century. The contribution of Ye. Ozarkevych as the founder of Ukrainian medical science in Halychyna is emphasized. It is concluded that in the studied period, doctors-scientists were the authors of journalistic works and fiction.
\end{abstract}

Key words: Halychyna; medical science; Shevchenko Scientific Society in Lviv; Ukrainian doctors; fiction.

\footnotetext{
Анотація. У статті проаналізовано діяльність окремих українських лікарів Галичини, які були письменниками, у розвиток освіти, науки, висвітлено творчі здобутки І. Горбачевського, Я. Окуневського, С. Окуневської-Морачевської, Є. Озаркевича та інших крізь призму діяльності Наукового товариства імені Шевченка у Львові на початку ХХ ст. Наголошено на внеску $€$. Озаркевича як основоположника української медичної науки в Галичині. Зроблено висновок, що в досліджуваний період учені-медики були авторами публіцистичних та художніх творів.
}

Ключові слова: Галичина; медична наука; Наукове товариство імені Шевченка у Львові; українські лікарі; художня література.

(c) H. V. Bilavych, M. A. Bahriy, I. V. Bilavych et al. 
Introduction. Scientific societies are one of the most interesting and at the same time the least studied phenomena of Ukrainian culture. The Shevchenko Scientific Society (ShSS) in Lviv played a significant role in development of science and culture of Ukraine in the late XIX - early XX centuries.

The conscious intellectuals, in particular doctors, participated in the work of Ukrainian cultural and educational organizations of Western Ukraine, in particular, such as the Prosvita Society, the Medychna Hromada, the Ukrainian Medical Society, the Ukrainian Hygienic Society, and the Vidrodzhennia Society. ShSS had an important place in the activity of doctors. The Shevchenko Society followed the path of the Prosvita Society, playing a vital role in formation a full-fledged Ukrainian civil society on the Ukrainian lands of the Austro-Hungarian Empire, as a form of national activity in all spheres of the people's public life.

The aim - to analyze the contribution of doctors, members of the Shevchenko Scientific Society in Lviv to the development of Ukrainian education, science and literature (late XIX - early XX century).

Theoretical framework. The ShSS emerged in Lviv in 1873 as a literary publishing organization that published literary and scientific works and journals, in every way facilitated development of Ukrainian literature. Progressive cultural figures, cultural and educational organizations spread and promoted the works of Ukrainian writers-educators. In spite of small achievements in scientific or publishing activity, it played a significant role in the development of Ukrainian pedagogical thought.

The structure of the ShSS was defined by three sections: historical-philosophical, philological and mathematical-natural-medical. Five commissions were in operation at the beginning of the ShSS, one of the primary and fundamental commissions was the linguistic one. M. Hrushevsky, the head of the ShSS, attracted students and young teachers to work. He edited "Notes of the Shevchenko Scientific Society" and it was thanks to his organizational skills that more than 100 volumes of it were published $[1,12]$.

Among the members of the ShSS were also physicians, engaged in scientific, literary, and journalistic activities. Despite the considerable imperfection of the healthcare system in the AustroHungarian Empire, it managed to give impetus to the emergence and further development of Ukrainian medicine and the formation of medical intelligentsia. It was facilitated by the emergence of many Ukrainian medical institutions, professional scientific societies, which were mentioned above [12].

The mathematical-natural-medical section had its own printed edition that was coming out from 1898 to 1901 as a "Collection" of scientific works. Ukrainian doctors (I. Horbachevskyi, Ye. Ozarkevych, T. Hvozdetskyi, Shch. Selskyi, V. Hukevych, M. Dolynskyi, Ye. Kobrynskyi, etc.) published their works in it. Scientists from other countries $[7,11]$ spread the ideas of public medical education among the Ukrainian people of the region as well.

In the context of this process, we distinguish the activity of the Medical Commission (MC of ShSS), which was created in 1898 at the mathematicalnatural-medical section of the ShSS. Ukrainian scientist, doctor, and the head of the Ukrainian medical movement, Yevhen Ozarkevych, played the decisive role here.

Among the founders of Ukrainian medical science there were M. Vakhnyanyn, O. Dakur, S. MorachevskaOkunevska, L. Kossak, P. Sushkevych, Shch. Selskyi, and others. We note an interesting and original phenomenon in the development of Ukrainian medical science and in the establishing of public healthcare system, when famous doctors of Przemysl, Vienna, Prague, and Dnieper Ukraine were part of the ShSS. The greatest achievement in the field of Ukrainian medical science was the creation of Ukrainian medical terminology, scientific medical literature in Ukrainian, the appearance of scientific works from all areas of medical fields of study [7].

Under the guidance of Ye. Ozarkevych, since 1898, the Medical Collection ("Likarskyi Zbirnyk") was published. It was a large-scale scientific edition (the issue has 90-100 pages and consisted of three sections: original scientific articles, statistical reports of the commission's activity and terminology). The Medical Collection played a significant role in the spreading of medical knowledge among Ukrainians of Galicia, becoming a kind of medical encyclopedia for the people of the region (for example, Ye. Ozarkevych published about 100 works on various subjects) [3].

Ivan Horbachevskyi (1854-1942), the most prominent Ukrainian scientist in the Austro-Hungarian Empire, made a significant contribution to the development of Ukrainian academic medicine and the national healthcare system. He was born in the village of Zarubyntsi of Ternopil district. He came from a priest's family. After graduating from the University of Vienna (1873-1877), Ivan Horbachevskyi soon was recognized 
by European scientific community, synthesizing uric acid in 1882. The following year the young scientist became the head of the newly created department of medicinal chemistry at Charles University in Prague. I. Horbachevskyi simultaneously embodied the national idea: he was an active member of the Hromada society and the Sich society, since 1899 - a full member of the ShSS [11]. The scientist collaborated with Ukrainian researchers and physicians in Lviv. On October 4, 1911 he was elected as the chairman of the mathematicalnatural-medical section, which he headed until 1918. The main merit of this work was the implementation of the project of creation Ukrainian scientific terminology in the fields of medicine and chemistry $[1,7,12]$.

An extraordinary event in the life of I. Horbachevskyi and, surely, in development of not only domestic but also European medicine, was the launching of specialized Ministry of Public Health in 1917 (the first in the world) as a separate structural unit of the Austro-Hungarian Government. I. Horbachevskyi developed the project of the Ministry of Health and became its first minister (from July 20, 1918 - until the end of October 1918) [1, 7, 12]. He had working experience in such structures as a member of the Regional Sanitary Council in Prague, a member of the Supreme Sanitary Council in Vienna (1906). It is natural that I. Horbachevskyi made a great deal of effort to create the Ukrainian Free University in 1921, which he headed in 1923 [2].

It is not surprising that his daughter, Sofiia Okunevska (1865-1926), also wanted to become a doctor. She entered the history of domestic medicine as the first woman doctor in Halychyna. She was also the first Ukrainian in the region, who in 1885 graduated from Lviv academic gymnasium. When making the final exam an audience was crowded, there were Ivan Franko, Ivan Nechui-Levytskyi, Oleksandr Konyskyi with his daughter, Ivan Belei, etc. In 1887 Sofiia entered the University of Zurich to the Medical Faculty and successfully graduated from it in 1895 and earned a doctorate (Doctor of Medicine degree). Sofiia Okunevska became the first woman doctor in the AustroHungarian Empire and the first woman in Western Ukraine, which gained university education [3, 8].

Sofiia Okunevska worked in Lviv "Narodna Lichnytsia" that was led by her relative, known scientist and public figure, Yevhen Ozarkevych. Here, in Lviv, Sofiia Okunevska created a school of obstetricians and gynecologists and for the first time in Western Ukraine organized courses for nurses and midwives. For her great kindness, responsive heart and a friendly attitude to the patients they called her "St. Sofiia" [3]. Sofiia Okunevska worked on scientific problems, helped Ye. Ozarkevych to conclude the Dictionary of Ukrainian medical terminology participated in the publication of the medical journal "Zdorovlie", printed scientific works [8]. With the assistance of Ivan Franko, in June 1887 Sofia Okunevska took part in the preparation and publication of the first women's almanac "The First Wreath" (it had 464 pages) in the Lviv printing house of the Shevchenko Scientific Society, edited by Olena Pchilka and Natalia Kobrynska.

In "The First Wreath" almanac, female authors were published. 43 original prose works, poems, ethnographic explorations, scientific articles of 17 authors were collected in it. Sofia Okunevska made her debut under the literary pseudonym of Yeryna XXX. She published a story on urban life called "Sand. Sand!” as well as an ethnographic exploration called "Family bondage in wedding songs and rituals".

Work on the publication of "The First Wreath" brought Sofia Okunevska closer to Ivan Franko, who supported the girl in her striving for higher education.

Sofia Okunevska was a member of Shevchenko Scientific Society, she wrote scientific articles. She worked productively in the Medical Commission established in 1897 that was the first organization of Ukrainian doctors. She helped Ye. Ozarkevych compile a dictionary of Ukrainian medical terminology and participated in the publication of the medical journal "Health". In 1908 she published the work called "The effect of temperature on the osmotic pressure of erythrocytes", which was republished many times.

From a young age, she was well-oriented in public life and was acquainted with most of the writers of that time who lived in Western Ukraine. In general, Sofia was a very talented and erudite person who was admired by Ivan Franko and Vasyl Stefanyk.

Since her young years, Sofia Okunevska became a good friend with Olga Kobylianska. She and Natalia Kobrynska had a great influence on Olga. It was Sofia Okunevska and Natalia Kobrynska who encouraged the future outstanding writer to start writing in Ukrainian and in every way helped her. Not only did Sofia translate Kobylianska's early novels, but she also took care to have them printed.

Sofia Okunevska wrote literary essays, was distinguished by a brilliant epistolary style, masterfully played the piano, and especially skillfully performed works by Frederic Chopin. 
Friendship with Sofia Okunevska pushed Olga Kobylianska to write a number of works, in almost every one of which (from "Man” to “Apostol Cherni”) there is an image of Sophia under the names of different characters, endowed with an extraordinary appearance and strong character.

One of the most famous Ukrainian doctors in Halychyna was Yaroslav Okunevskyi. He made brilliant career in the military medicine. In 1877 he entered the University of Vienna, the Faculty of Medicine. In 1884 Ya. Okunevskyi began to serve as ship's doctor of the Austria-Hungary's navy, which was based in Croatia in city of Pula. He visited not only Europe and Asia, but also Africa, America and Oceania. His medical practice was highly awarded numerous awards by many sea states [4].

He was the author of the world's first Charter of Medical Service in Naval Forces (1900). Later, in 1914, he was promoted to Major General of Maritime Medical Service. Under his guardianship were thousands of sailors. At the beginning of World War II with the rank of rear admiral he was the head of Medical Service of the Admiralty of Habsburg fleet where he had worked with his colleagues and subordinated Ukrainian doctors - Captain V. Verbenets, Colonel O. Zarytskyi and Colonel M. Rozhankovskyi etc [6].

Ya. Okunevskyi was Chief Doctor and Chief of the Main Medical Department of the Staff of naval forces of the Austro-Hungarian Empire. For great merits (30 years of service) he became the first Ukrainian who was promoted to the Chevalier of Knight's Cross of Franz Joseph, the Knight of the Order of the Spanish queen, the French Legion of Honor, the Chinese Imperial Order of the Dragon, the highest title of Mandarin and many more awards. Ya. Okunevskyi perfectly possessed of military and medical knowledge, versed in the navigation and geography, fluently spoke English, French, Italian and German [4, 5].

At the time of national liberation struggle Rear Admiral Ya. Okunevskyi organized Ukrainian sanitary service and headed it. He supplied the drugs for the Legion of Ukrainian Sich Riflemen, helped their sanitary service, donated funds and more. After proclamation of the West Ukrainian People's Republic he headed the State Medical Mission in Vienna. He provided medical supplies for Halychyna. He sent four sanitary trains for Ukrainian Galician Army. Ya. Okunevskyi contributed to the creation of the First Hutsul Regiment of the Marine Corps, which consisted mostly of the former Austro-Hungarian sailors [2]. Yaroslav Okunevskyi visited almost all countries of the Mediterranean basin. This gave an impetus to write essays about the countries in which he traveled, called "Letters from a foreign land" - a kind of vivid picture of Europe, Asia and northeast Africa of the late XIX century [9].

To characterize the development of the Ukrainian medical science of the studied period, the word "first" is appropriate: the first Ukrainian medical scientific institution, the first outpatient clinic ("Narodna Lichnytsia"), the first Ukrainian medical scientific journal ("Likarskyi Visnyk"), the first Ukrainian Medical Society (UMS), the first Secret Medical Courses, the first Ukrainian Higher School (UHS), the first Ukrainian Hospital named after A. Sheptytskyi, the first Ukrainian-language popular scientific medical journal ("Zdorovlie”), the first female scientist, the first female student of medicine, the first female professor (S. Okunevska-Morachevska), the first medical scientist (I. Horbachevskyi), the first scientific articles on health resort (Ye. Ozarkevych), the first Ukrainian scientific medical terminology (Ye. Ozarkevych), the first doctor-radiologist (M. Panchyshyn), the first Minister of Health in the world (I. Horbachevskyi), the first Ukrainian doctor-electrocardiogram (R. Osinchuk),the first Ukrainian-language textbooks on psychology and logic (S. Balei) and so on [11].

Conclusions and Prospects for Research. It is proved that such preconditions and factors as democratic character of domestic policy of the Austro-Hungarian monarchy, the reformation of education and health care systems, creation of a legislative framework for the activities of public associations, etc., have become an important basis for the self-organization of Ukrainians, Ukrainian national movement development, creation of the first Ukrainian medical societies, the birth of Ukrainian science, emergence of a cohort of outstanding figures in the medical sphere (I. Horbachevskyi, Ye. Ozarkevych, S. Okunevska-Morachevska, Ya. Okunevskyi, etc.), institutionalization of Ukrainian public health care in the form of medical, scientific, charitable and other community initiatives (Society of Galician Physicians, Medical Commission of Shevchenko Scientific Society, "Medical Community", "Lviv Polyclinic", "Narodna Litchnytsya”, Ukrainian Medical Societies (UMS), Ukrainian Hygiene Society (UHS), etc.). 


\section{Materials of International Scientific and Practical Conference \\ “PROFESSIONAL AND COMMUNICATION CULTURE OF THE FUTURE DOCTOR: LINGUISTIC, PEDAGOGICAL AND PHILOSOPHICAL ASPECTS”}

\section{List of literature}

1. Барвінський О. Про заснованєі дотеперішній розвиток товариства ім. Шевченка у Львові / О. Барвінський // Зап. НТШ. - 1892. - Т. 1. - С. 209-212.

2. Білавич І. Передумови створення громадського медичного просвітництва та лікарської опіки в Галичині на початку XX ст. / І. Білавич // Молодь і ринок. - 2015. № 1. - С. 133-136.

3. Ганіткевич Я. Євген Озаркевич - один із засновників новітньої української медицини (До 150-річчя від дня народження) [Електронний ресурс] / Я. Ганіткевич. Режим доступу : http://ntsh.org/content/ievgenozarkevichodin-iz-zacnovnikiv-novitnoyi-ukrayinskoyimedicini-do150-richchya-vid.

4. Ганіткевич Я. Історія української медицини в датах та іменах / Я. Ганіткевич. - Львів, 2004. - 365 с.

5. Ганіткевич Я. Українська медицина Львова до початку Другої світової війни [Електронний ресурс] / Я. Ганіткевич. - Режим доступу : http:// ntsh.org/.../ukrayinskamedicina-lvova-do-pochatku-drugoyi-svitovoyi-viyni.

6. Ганіткевич Я. Ярослав Окуневський - видатний лікар, генерал медичої служби Австро-Угорського флоту, український національно-просвітницький діяч /
Я. Ганіткевич // Вісник соціальної гігієни та організації охорони здоров’я України. - 2012. - № 2. - С. 104-115.

7. Гвоздецький Т. Участь українських лікарів на заграничних лікарських конгресах перед війною / Т. Гвоздецький // Лікарський вісник. - 1931. - Ч. 2-3. С. 34-38.

8. Кізера О. Софія Атанасівна Окуневська-Морачевська - перша жінка Буковини і Галичини / О. Кізера, О. Кізера, Н. Кізера // Жіночий лікар. - 2011. - № 1. C. 48-49.

9. Окуневський Я. Листи з чужини : літ.-худ. вид. / Я. Окуневський. - К. : Темпора, 2009. - 520 с.

10. Олесницький Б. Наші лікарі / Б. Олесницький // Альманах Станиславівської землі. - Нью-Йорк ; Торонто ; Мюнхен, 1975. - С. 603-613.

11. Пантюк М. Наука як чинник розвитку суспільної медичної опіки в Галичині наприкінці XIX - на початку XX сторіччя / М. Пантюк, I. Білавич // Молодь і ринок. 2018. - № 3. - С. 6-11.

12. Студинський К. Наукове товариство ім. Шевченка у Львові (1873-1928) / К. Студинський. - Львів, 1928. 125 c.

\section{References}

1. Barvinskyi, O. (1892). Pro zasnovanie i doteperishnii rozvytok tovarystva im. Shevchenka u Lvovi [About the founding and present development of the Shevchenko Society in Lviv]. Zap. NTSh. - Notes of ShSS, 1, 209-212 [in Ukrainian].

2. Bilavych, I. (2015). Peredumovy stvorennia hromadskoho medychnoho prosvitnytstva ta likarskoi opiky v Halychyni na pochatku XX st. [Preconditions of forming of public education and health care in Galicia in early XXth century]. Molod i rynok - Youth and Market, 1, 133-136 [in Ukrainian].

3. Hanitkevych, Ya. Yevhen Ozarkevych - odyn iz zasnovnykiv novitnoi ukrainskoi medytsyny (Do 150-richchia vid dnia narodzhennia) [Yevhen Ozarkevych - one of the founders of the newest Ukrainian medicine (To the 150th anniversary of his birth)]. Retrieved from: http://ntsh.org/ content/ievgenozarkevich-odin-iz-zacnovnikiv-novitnoyiukrayinskoyimedicini-do-150-richchya-vid [in Ukrainian].

4. Hanitkevych, Ya. (2004). Istoriia ukrainskoi medytsyny $v$ datakh ta imenakh. NTSh ta in [History of Ukrainian medicine in dates and names. ShSS and others]. Lviv [in Ukrainian].

5. Hanitkevych, Ya. Ukrainska medytsyna Lvova do pochatku Druhoi svitovoi viiny [Ukrainian Medicine of Lviv before the Second World War]. Retrieved from: ntsh. org/.../ukrayinska-medicina-lvova-do-pochatku-drugoyisvitovoyi-viyni [in Ukrainian].

6. Hanitkevych, Ya. (2012). Yaroslav Okunevskyi vydatnyi likar, heneral medychoi sluzhby Avstro-Uhorskoho flotu, ukrainskyi natsionalno-prosvitnytskyi diiach [Yaroslav Okunevskyi - outstanding physician, general of the medical service of the Austro-Hungarian Navy, Ukrainian national educator]. Visnyk sotsialnoi hihiieny ta orhanizatsii okhorony zdorovia Ukrainy - Bulletin of Social Hygiene and Organization of Healthcare of Ukraine, 2, 104-115 [in Ukrainian]. 7. Hvozdetskyi, T. (1931). Uchast ukrainskykh likariv na zahranychnykh likarskykh kongresakh pered viinoiu [The participation of Ukrainian doctors at foreign medical congresses before the war]. Likarskyi visnyk-Doctor's Bulletin, 2-3, 34-38 [in Ukrainian].

8. Kizera, O., Kizera, O., \& Kizera, N. (2011). Sofiia Atanasivna Okunevska-Morachevska - persha zhinka Bukovyny i Halychyny [Sofia Atanasivna OkunevskaMorachevskaya - the first woman of Bukovina and Galicia]. Zhinochyi likar - Women's Doctor, 1, 48-49 [in Ukrainian]. 9. (2009). Yaroslav Okunevskyi. Lysty z chuzhyny: literaturno-khudozhnie vyzhannia [Yaroslav Okunevsky. Letters From a Foreign Country: A Literary and Artistic Edition]. Kyiv: Tempora [in Ukrainian].

10. Olesnytskyi, B. (1975). Nashi likari [Our doctors]. Almanakh Stanyslavivskoi zemli. New-York-TorontoMunich [in Ukrainian].

11. Pantiuk, M., \& Bilavych, I. (2018). Nauka yak chynnyk rozvytku suspilnoi medychnoi opiky v Halychyni naprykintsi 
XIX - na pochatku XX storichchia [The scienceas a factor of development of social health care in Galicia at the end of the XIX cetury to the beginning of the XX century]. Molod i rynok - Youth and Market, 3, 6-11 [in Ukrainian].
12. Studynskyi, K. (1928). Naukove tovarystvo im. Shevchenka u Lvovi (1873-1928) [Shevchenko Scientific Society in Lviv (1873-1928)]. Lviv [in Ukrainian].

Received 27.04.20 Recommended 29.04.20 